\title{
Dimethyl sulfoxide at high concentrations inhibits non-selective cation channels in human erythrocytes
}

\author{
Oleg A. Nardid ${ }^{1}$, Miroslav I. Schetinskey ${ }^{1}$ and Yuliya V. Kucherenko ${ }^{1,2}$ \\ ${ }^{1}$ Institute for Problems of Cryobiology and Cryomedicine of the Ukrainian National Academy of Sciences, Kharkov 61015 , \\ Ukraine \\ ${ }^{2}$ Department of Physiology Institute I, Eberhard-Karls University of Tübingen, D-72076 Tübingen, Germany
}

\begin{abstract}
Dimethyl sulfoxide (DMSO), a by-product of the pulping industry, is widely used in biological research, cryobiology and medicine. On cellular level DMSO was shown to suppress NMDA-AMPA channels activation, blocks $\mathrm{Na}^{+}$channel activation and attenuates $\mathrm{Ca}^{2+}$ influx (Lu and Mattson 2001). In the present study we explored the whole-cell patch-clamp to examine the acute effect of high concentrations of DMSO (0.1-2 mol/l) on cation channels activity in human erythrocytes. Acute application of DMSO (0.1-2 mol/l) dissolved in $\mathrm{Cl}^{-}$-containing saline buffer solution significantly inhibited cation conductance in human erythrocytes. Inhibition was concentration-dependent and had an exponential decay profile. DMSO ( $2 \mathrm{~mol} / \mathrm{l})$ induced cation inhibition in $\mathrm{Cl}^{-}$- containing saline solutions of: $40.3 \pm 3.9 \%$ for $\mathrm{K}^{+}, 35.4 \pm 3.1 \%$ for $\mathrm{Ca}^{2+}$ and 47.4 $\pm 1.9 \%$ for $\mathrm{NMDG}^{+}$. Substitution of $\mathrm{Cl}^{-}$with gluconate ${ }^{-}$increased the inhibitory effect of DMSO on the $\mathrm{Na}^{+}$current. Inhibitory effect of DMSO was neither due to high permeability of erythrocytes to DMSO nor to an increased tonicity of the bath media since no effect was observed in $2 \mathrm{~mol} / \mathrm{l}$ glycerol solution. In conclusion, we have shown that high concentrations of DMSO inhibit the non-selective cation channels in human erythrocytes and thus protect the cells against $\mathrm{Na}^{+}$and $\mathrm{Ca}^{2+}$ overload. Possible mechanisms of DMSO effect on cation conductance are discussed.
\end{abstract}

Key words: DMSO — Cation channels - Patch-clamp

\section{Introduction}

Dimethyl sulfoxide (DMSO), a by-product of the pulping industry, is extensively utilized as a solvent in biological research. It is also widely used as a preservative for bone marrow cells and organs (Boiko et all. 1982; Small and Goldstein 1982; Motta et al. 2010; Brockbank et al. 2011; Haack-Sørensen and Kastrup 2011). It shows radioprotective (Goddu et al. 1996) and antioxidant properties (Repine et al. 1981; Mobarok 1998; Dkhar and Sharma 2010), antitumor activity (Fahim et al. 2003), and inhibits necrosis of the cells (Camici et al. 2006; Iida et al. 2007). Medical doctors prescribe it for a variety of ailments including pain, inflammation, scleroderma, interstitial cystitis and arthritis, and elevated intracranial pressure (Goodnough et al. 1980; Karaca et al.

Correspondence to: Yuliya V. Kucherenko, Institute for Problems of Cryobiology and Cryomedicine of the Ukrainian National Academy of Sciences, Kharkov 61015, Ukraine

E-mail: yulia_kucherenko@yahoo.com
1991; McGee et al. 1991; Brien et al. 2008; Kim et al. 2011). For the variety of its positive effects it is considered to be the aspirin of our era. DMSO, alone or in combination with synergistic molecules, may help to neutralize pathological products harmful to the heart and brain in medical disorders involving head and spinal cord injury, memory dysfunction, and ischemic heart disease (Goodnough et al. 1980; Jacob and de la Torre 2009; Parisi et al. 2010).

DMSO demonstrates a strong inhibitory effect on platelet aggregation (Dujovny et al. 1983), presumably via the inhibition of prostaglandin platelet-aggregating arachidonic acid metabolites (Asmis et al. 2010). No post-thrombotic consequences for platelet disaggregation were reported in humans or animals following high dose of DMSO administration (Dujovny et al. 1983). The experiments on human erythrocytes also showed lower cell aggregation indexes in DMSO treated cells (Santos et al. 2002).

On cellular level DMSO was shown to suppress NMDAAMPA channels activation, blocks $\mathrm{Na}^{+}$channel activation and attenuates $\mathrm{Ca}^{2+}$ influx ( $\mathrm{Lu}$ and Mattson 2001). 
However, the reported effects of DMSO are controversial and not always positive. DMSO was shown to produce widespread apoptosis in developing central nervous system and can cause cardiotoxicity in mice (Hanslick et al. 2009). Nevertheless, the documented side-effects of DMSO administration are relatively mild and relate to high concentration used for the treatment (25-40\% DMSO intravenously). Intravascular haemolysis due to high DMSO permeability in erythrocytes was reported in higher than 30\% DMSO solutions (Karaca et al. 1991).

In erythrocytes the use of high dose of DMSO was shown to inhibit acetylcholinesterase (Jagota 1992), oxidize glutathione (Homer et al. 2005) and enhance hexose monophosphate shunt activity (Adler et al. 1991). Conflicting data on DMSO effect on Ca-ATPase activity show an inhibition (Rybczyńska and Chmiel 1982; Romero 1992; McConnell et al. 1999) as well as an activation (Benaim and de Meis 1990; Lehotsky et al. 1992) of $\mathrm{Ca}^{2+}$-pump by high DMSO concentrations.

Since mature human erythrocyte are lacking intracellular $\mathrm{Ca}^{2+}$ stores (mitochondria and endoplasmic reticulum), a balance between the activities of Ca-ATPase and ion channels permeable to $\mathrm{Ca}^{2+}$ keeps intracellular free calcium concentration $\left(\left[\mathrm{Ca}^{2+}\right]_{\mathrm{i}}\right)$ at low levels (less than $100 \mathrm{nmol} / \mathrm{l}$; Tiffert et al. 2003). Ion channels which can rapidly increase intracellular $\mathrm{Na}^{+}$and $\mathrm{Ca}^{2+}$ concentrations play a key role in regulation of the cells survival. However, the data concerning the effect of DMSO on cation channels activity is missing and our study aims to provide the missing data.

Human erythrocytes were shown to express several types of non-selective cation channels permeable for $\mathrm{Ca}^{2+}:$ i) the voltage-gated channel, coupled to an acetylcholine receptor (Bennekou et al. 1993, 2004; Kaestner et al. 1999) and ii) the voltage-independent cation channels activated by oxidation, osmotic shock, energy depletion (Huber et al. 2001) and prostaglandin $\mathrm{PGE}_{2}$ (Lang et al. 2005).

The present study was performed to show the effect of high concentrations of DMSO, used in cryobiological and medical practice, on cation channels activity in human red blood cells.

\section{Materials and Methods}

\section{Erythrocytes}

Erythrocytes were drawn from healthy volunteers, who signed informed consent, or provided by the blood bank of the University of Tübingen from banked erythrocyte concentrates. Erythrocytes were washed twice $(1200 \times g$, $5 \mathrm{~min}, 22^{\circ} \mathrm{C}$ ) in $5 \mathrm{mmol} / \mathrm{l}$ glucose-containing $\mathrm{NaCl}$ Ringer bath solution ( $\mathrm{pH} 7.4$, see below).

\section{Electrophysiology}

Patch-clamp whole-cell recordings were performed at room temperature. The patch electrodes were made of borosilicate glass capillaries (150 TF-10, Clark Medical Instruments) using a horizontal DMZ puller (Zeitz, Martinsried, Germany). Pipettes with high resistance from 17 to $20 \mathrm{MOhm}$ were connected via an $\mathrm{Ag}$ - $\mathrm{AgCl}$ wire to the headstage of EPC 9 patch-clamp amplifier (HEKA Elektronik Dr. Schulze GmbH, Germany). Data acquisition and data analysis were controlled by a computer equipped with an ITC 16 interface (InstruTech, HEKA Elektronik Dr. Schulze GmbH, Germany) and Pulse software (HEKA Elektronik Dr. Schulze GmbH, Germany). For current measurements, erythrocytes were held at a holding potential $\left(\mathrm{V}_{\mathrm{h}}\right)$ of $-10 \mathrm{mV}$ and $200 \mathrm{~ms}$ pulses from -100 to $+100 \mathrm{mV}$ were applied with increments of $+20 \mathrm{mV}$. The original current traces are depicted without filtering (acquisition frequency of $3 \mathrm{kHz}$ ). The currents were analyzed by averaging the current values measured between 90 and $190 \mathrm{~ms}$ of each square pulse (currentvoltage relationship). The applied voltages refer to the cytoplasmic face of the membrane with respect to the extracellular space. The offset potentials between both electrodes were zeroed before sealing. The liquid junction potentials between bath and pipette solutions and between the bath solutions and the salt bridge (filled with $\mathrm{NaCl}$ bath solution) were calculated according to Barry and Lynch (1991). Data were corrected for liquid junction potentials. Recordings were obtained after reaching $>10$ $\mathrm{G} \Omega$ seal in on-cell configuration.

The pipette solution consisted of (in mmol/l): 125 Na-gluconate, $10 \mathrm{NaCl}, 1 \mathrm{MgCl}_{2}, 1 \mathrm{MgATP}, 1$ EGTA, 10 $\mathrm{HEPES} / \mathrm{NaOH}$ ( $\mathrm{pH}$ 7.4). The $\mathrm{NaCl}$ Ringer bath solution contained (in mmol/l): $145 \mathrm{NaCl}, 5 \mathrm{KCl}, 2 \mathrm{MgCl}_{2}, 1 \mathrm{CaCl}_{2}$, 5 glucose, $10 \mathrm{HEPES} / \mathrm{NaOH}$ (pH 7.4). In the experiments where $\mathrm{Cl}^{-}$was substituted with gluconate, the solution contained (in mmol/l): $150 \mathrm{Na}$-gluconate, $2 \mathrm{MgCl}_{2}$, $1 \mathrm{CaCl}_{2}, 5$ glucose, and $10 \mathrm{HEPES} / \mathrm{NaOH}$ ( $\mathrm{pH}$ 7.4). The $\mathrm{KCl}, \mathrm{NaCl}, \mathrm{NMDG}-\mathrm{Cl}$, and $\mathrm{CaCl}_{2}$ bath solutions contained (in $\mathrm{mmol} / \mathrm{l}$ ) either $150 \mathrm{KCl}, 150 \mathrm{NaCl}, 180 \mathrm{NMDG}$, or 100 $\mathrm{CaCl}_{2}, 10 \mathrm{HEPES}$ (titrated with $\mathrm{HCl}, \mathrm{NMDG}$ or $\mathrm{CaOH}$ to $\mathrm{pH}$ 7.4). DMSO/glycerol (0.1-2 mol/l), dissolved in Ringer or $150 \mathrm{mmol} / \mathrm{l} \mathrm{Na-gluconate} \mathrm{bath} \mathrm{solutions,} \mathrm{were}$ added acutely. Concentrations of DMSO (glycerol) were increased gradually starting with the lowest $(0.1 \mathrm{~mol} / \mathrm{l})$ $\mathrm{DMSO} /$ glycerol concentration to avoid cell lysis due to osmotic shock in highly concentrated (1-2 mol/l) DMSO and glycerol solutions. The recordings were made after reaching a steady state (5-10 min incubation in DMSO/ glycerol media).

Reagents were obtained from Sigma (Germany) and were of the highest grade. 
Intracellular $\mathrm{Ca}^{2+}$

Experiments were performed on erythrocytes loaded with $2 \mathrm{~mol} / \mathrm{l}$ DMSO. Composition of the bath solution was following (in mmol/l): $145 \mathrm{NaCl}, 5 \mathrm{KCl}, 2 \mathrm{MgCl}_{2}, 1 \mathrm{CaCl}_{2}, 5$ glucose, $2 \mathrm{~mol} / \mathrm{l} \mathrm{DMSO}, 10 \mathrm{HEPES} / \mathrm{NaOH}$ (pH 7.4). Concentration of DMSO was gradually increased starting with $0.1 \mathrm{~mol} / \mathrm{l} \mathrm{DMSO}$ in the Ringer bath solution.

DMSO-treated erythrocytes $(0.4 \% \mathrm{Ht})$ were washed in Ringer solution containing $5 \mathrm{mmol} / \mathrm{C} \mathrm{CaCl}_{2}$ and $2 \mathrm{~mol} / \mathrm{l}$ $\mathrm{DMSO}$, then $2 \mu \mathrm{mol} / \mathrm{l}$ Fluo-3/AM was added (Calbiochem, Bad Soden, Germany). The cells were incubated at $37^{\circ} \mathrm{C}$ for $20 \mathrm{~min}$., washed once and re-suspended in $5 \mathrm{mmol} / \mathrm{Ca}^{2+}$. containing Ringer (in the presence of $2 \mathrm{~mol} / \mathrm{l} \mathrm{DMSO}$ ) and subsequently analyzed by flow cytometric analysis (FACSCalibur from Becton Dickinson; Heidelberg, Germany) in fluorescence channel FL-1 with excitation wavelength of 488 $\mathrm{nm}$ and emission wavelength of $530 \mathrm{~nm}$.

\section{Statistics}

Data is expressed as arithmetic means \pm SEM and the paired two-tailed t-test was employed as appropriate, $p<05$ was considered statistically significant.

\section{Results}

In the first series of experiments we examined the effect of acute application of DMSO on cation channel activity of human erythrocytes in $\mathrm{NaCl}$ Ringer bath solution.

Prior to DMSO application, erythrocyte cation conductance (measured as inward current slope of the current-voltage (I/V) relationship) approached the value of $68 \pm 2 \mathrm{pS}$ (Fig. 1B). The conductance declined significantly reaching values of $66 \pm 2 \mathrm{pS}(n=13 ; p \leq 0.05)$ following exposure to $0.1 \mathrm{~mol} / \mathrm{l} \mathrm{DMSO} ; 56 \pm 2 \mathrm{pS}$ for $0.5 \mathrm{~mol} / \mathrm{l}, 48 \pm 2 \mathrm{pS}$ for $1 \mathrm{~mol} / \mathrm{l}$ and $42 \pm 2 \mathrm{pS}$ for $2 \mathrm{~mol} / \mathrm{l} \mathrm{DMSO}$ solutions respectively $(n=$ $13 ; p \leq 0.001)$.

To check whether DMSO blocked cation (not $\mathrm{Cl}^{-}$) conductance in the next series of experiments we dissolved DMSO in isotonic Na-gluconate bath solution. A combination of $\mathrm{Na}$ gluconate bath and pipette solutions allowed us to characterize $\mathrm{Na}^{+}$influx. As it is shown in Fig. 2A and B, acute application of DMSO in Na-gluconate bath solution inhibited $\mathrm{Na}^{+}$conductance in human erythrocytes in concentration-dependent manner. Prior to DMSO application $\mathrm{Na}^{+}$conductance in isotonic Na-gluconate solution was higher $(130 \pm 29 \mathrm{pS})$ than that recorded in $\mathrm{NaCl}$ Ringer bath solution (Fig. 2B). The value decreased significantly in the presence of $2 \mathrm{~mol} / \mathrm{l} \mathrm{DMSO}$ and approached $95 \pm 16 \mathrm{pS}(n=7 ; p \leq 0.05)$.

Fitting of the experimental data showed an exponential decay profile in both $\mathrm{NaCl}$ and $\mathrm{Na}$-gluconate bath solutions

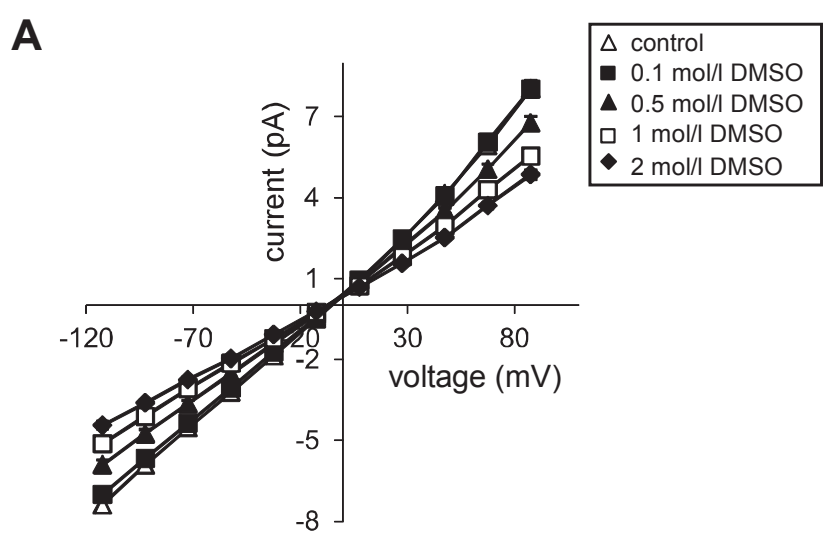

B
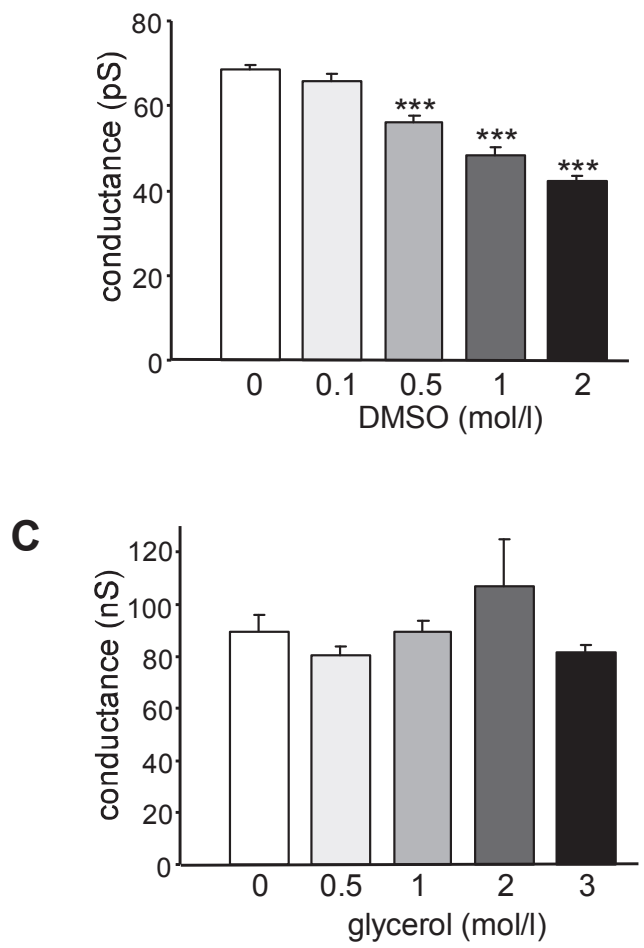

Figure 1. Acute application of DMSO dissolved in $\mathrm{NaCl}$ Ringer bath solution blocks cation conductance in human erythrocytes. A. Arithmetic means $( \pm \mathrm{SEM}, n=13)$ of the current as a function of voltage (I/V relationship) recorded in $\mathrm{NaCl}$ Ringer bath solution prior to control and following acute application of $0.1 \mathrm{~mol} / \mathrm{l}$; $0.5 \mathrm{~mol} / \mathrm{l} ; 1 \mathrm{~mol} / \mathrm{l}$ and $2 \mathrm{~mol} / \mathrm{l} \mathrm{DMSO}$ in $\mathrm{NaCl}$ Ringer bath solution. B. Arithmetic means ( \pm SEM, $n=13$ ) of the conductance (as calculated for the inward currents by linear regression) prior to control and following acute application of $0.1 \mathrm{~mol} / \mathrm{l} ; 0.5 \mathrm{~mol} / \mathrm{l} ; 1 \mathrm{~mol} / \mathrm{l}$ and $2 \mathrm{~mol} / \mathrm{l} \mathrm{DMSO}$ in $\mathrm{NaCl}$ Ringer bath solution. ${ }^{* * *}$ indicates significant difference from control ( $p \leq 0.001$; paired $t$-test). C. Arithmetic means ( \pm SEM,$n=3$ ) of the conductance (as calculated for the inward currents by linear regression) prior to control and following acute application of $0.5 \mathrm{~mol} / \mathrm{l} ; 1 \mathrm{~mol} / \mathrm{l} ; 2 \mathrm{~mol} / \mathrm{l}$ and $3 \mathrm{~mol} / \mathrm{l}$ glycerol in $\mathrm{NaCl}$ Ringer bath solution. 


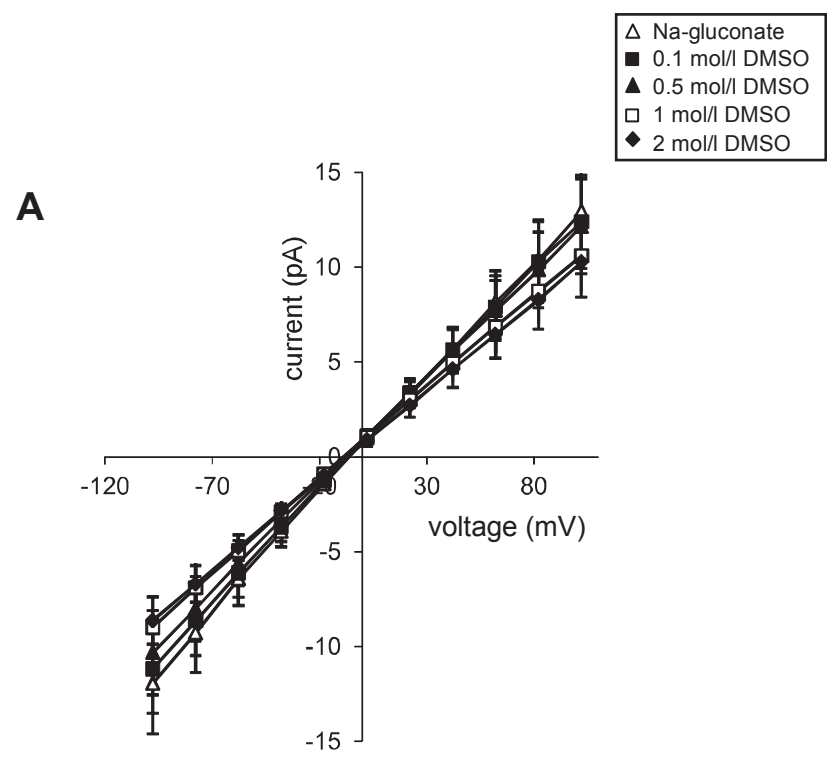

B

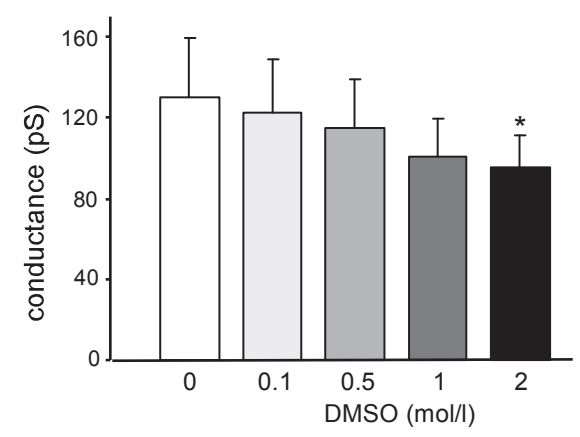

Figure 2. DMSO blocks $\mathrm{Na}^{+}$conductance in $\mathrm{Cl}^{-}$free medium. A. Arithmetic means $( \pm \operatorname{SEM}, n=8)$ of the current as a function of voltage (I/V relationship) recorded in $\mathrm{Na}$-gluconate bath solution prior to control $(\triangle)$ and following acute application of $0.1 \mathrm{~mol} / \mathrm{l}$; $0.5 \mathrm{~mol} / \mathrm{l} ; 1 \mathrm{~mol} / \mathrm{l}$ and $2 \mathrm{~mol} / \mathrm{l} \mathrm{DMSO}$ in Na-gluconate bath solution. B. Arithmetic means ( \pm SEM, $n=8$ ) of the conductance (as calculated for the inward currents by linear regression) prior to control $(\square)$ and following acute application of $0.1 \mathrm{~mol} / \mathrm{l} ; 0.5 \mathrm{~mol} / \mathrm{l}$; $1 \mathrm{~mol} / \mathrm{l}$ and $2 \mathrm{~mol} / \mathrm{l} \mathrm{DMSO}$ in Na-gluconate bath solution. ${ }^{*}$ significant difference from control ( $p \leq 0.05$, paired $t$-test).

(correlation coefficient (r) is 0.998 and 0.967 for $\mathrm{NaCl}$ and Na-gluconate bath solutions, respectively) (Fig. 3).

To define cation selectivity of DMSO sensitive cation conductance we substituted the $\mathrm{NaCl}$ Ringer bath solution with isotonic buffered NMDG-Cl, $\mathrm{CaCl}_{2}$ and $\mathrm{KCl}$ solutions. The I/V relationships for the cells in $180 \mathrm{mmol} / \mathrm{l} \mathrm{NMDG-Cl}, 100$ $\mathrm{mmol} / \mathrm{l} \mathrm{CaCl}{ }_{2}$ and $150 \mathrm{mmol} / \mathrm{l} \mathrm{KCl}$ bath solutions with and without $2 \mathrm{~mol} / \mathrm{l}$ DMSO are shown in Fig. 4A,B,C. As a result, DMSO inhibited inward (cation) currents irrespectively to positive charge carrier in extracellular bath solution (Fig.
A

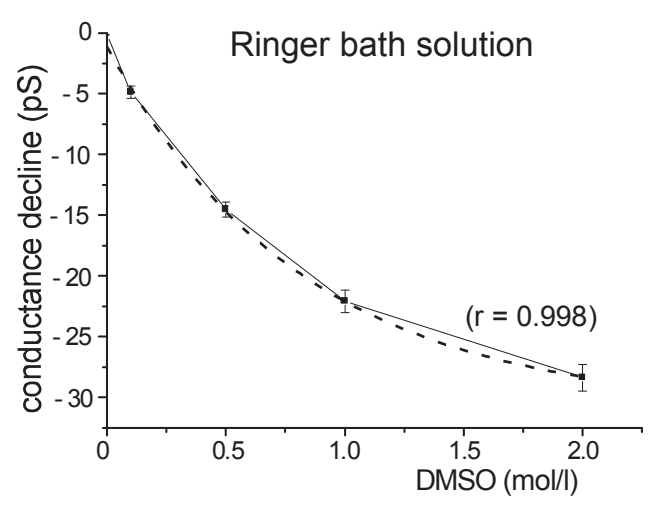

B

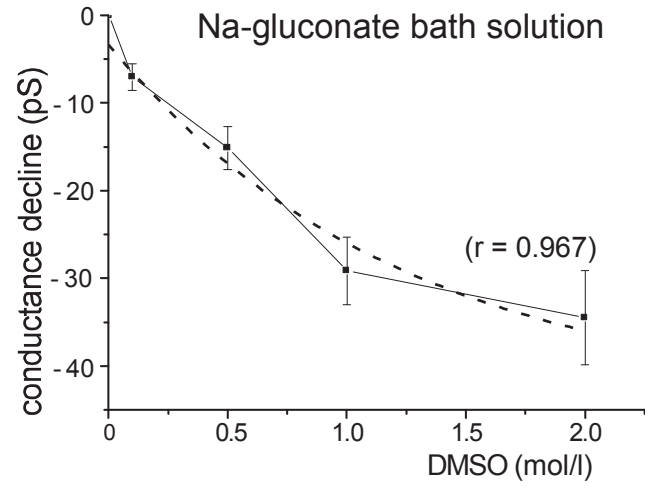

Figure 3. Exponential decay profile of the cation conductance decline in the presence of DMSO. A. Fitting of the experimental data for cation conductance inhibition by DMSO in $\mathrm{NaCl}$ Ringer bath solution (solid black line presents the original data while dotted black line depicts the exponential fitting ). B. as in A. for 150 $\mathrm{mmol} / \mathrm{l} \mathrm{Na}$-gluconate bath solution.

4D). According to the patch-clamp data, the inhibitory effect of DMSO on cation conductance of human erythrocytes in $\mathrm{Cl}^{-}$containing bath solutions was the following: $47.4 \pm 1.9 \%$ for $\mathrm{NMDG}^{+}, 40.3 \pm 3.9 \%$ for $\mathrm{K}^{+}, 35.4 \pm 3.1 \%$ for $\mathrm{Ca}^{2+}, 15.4$ $\pm 1.6 \%$ for $\mathrm{Na}^{+}$, and $39.2 \pm 1.1 \%$ for all the cations presented in the $\mathrm{NaCl}$ Ringer bath solution.

The blocking effect of $2 \mathrm{~mol} / \mathrm{l} \mathrm{DMSO}$ on $\mathrm{Na}^{+}$conductance depended on anion composition of the bath media and was reduced in $\mathrm{NaCl}$ bath solution in comparison with Na-gluconate (Fig. 4D). Activation of the non-selective cation channels stimulated by $\mathrm{Cl}^{-}$removal in Na-gluconate bath solution was blunted by $2 \mathrm{~mol} / \mathrm{l}$ DMSO (data are not shown).

To exclude the possibility that the blocking effect of high concentration of DMSO on non-selective cation channels in human erythrocytes may be due to high cellular osmolarity, we explored the effect of high concentrations of glycerol. Glycerol penetrates into the cells like DMSO. As shown in Fig. 1C, acute application of high concentrations of glycerol 
A

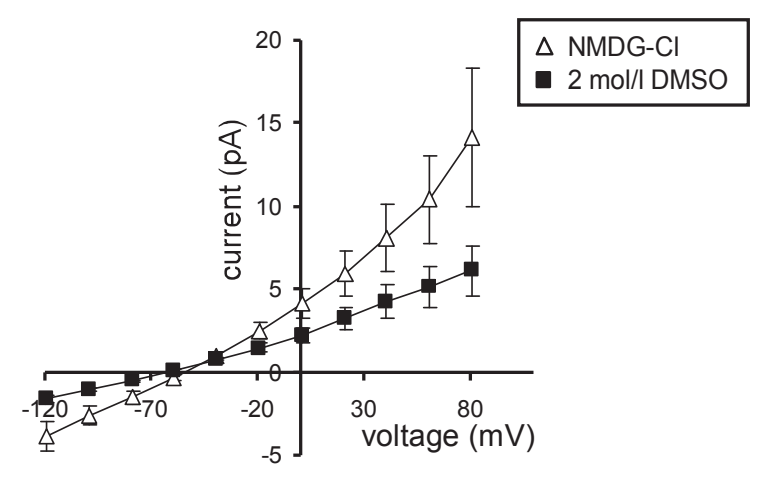

B

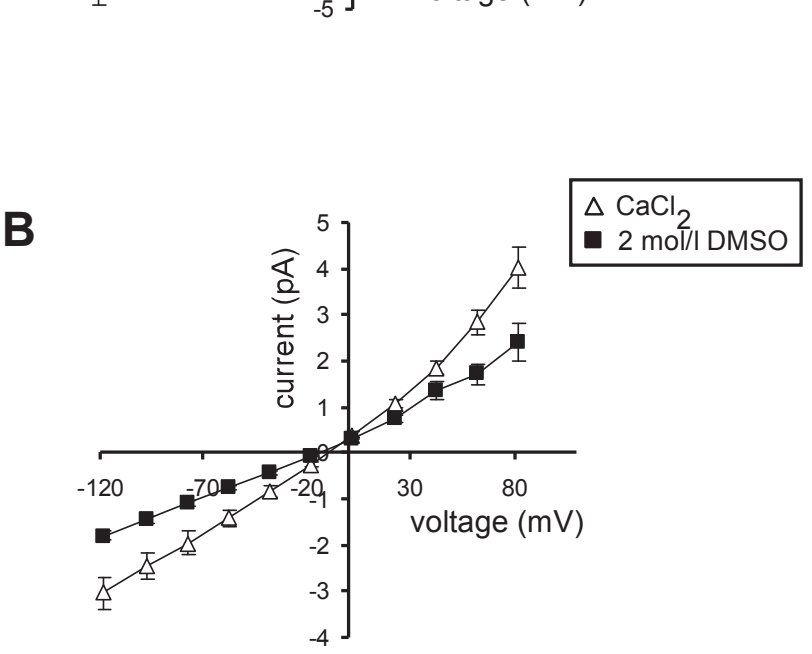

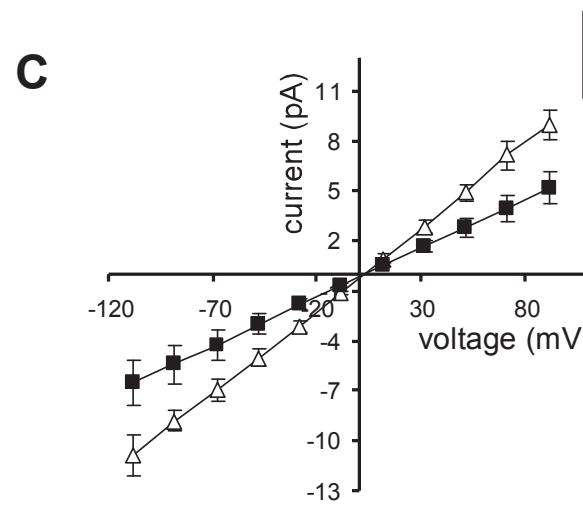

$\Delta \mathrm{KCl}$

- $2 \mathrm{~mol} / \mathrm{I} \mathrm{DMSO}$
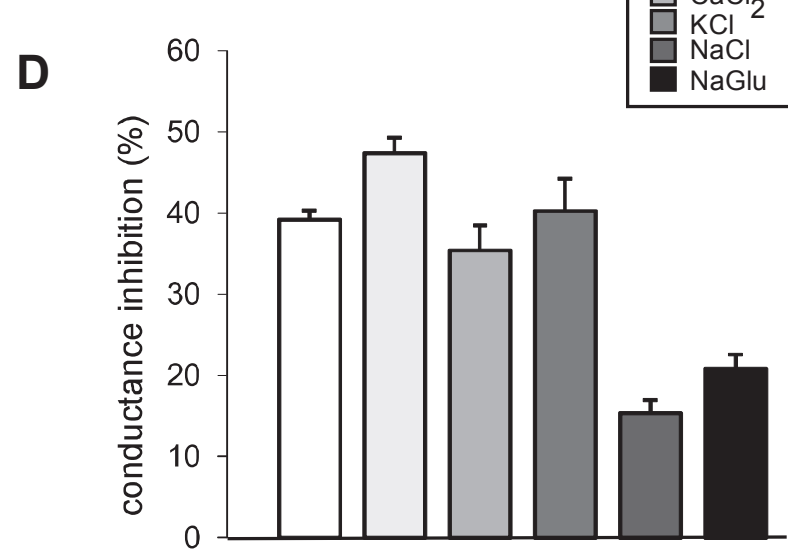

Figure 4. Non-selective inhibitory effect of $2 \mathrm{~mol} / \mathrm{l} \mathrm{DMSO}$ on cation conductance in human erythrocytes. A. Arithmetic means $( \pm S E M$, $n=6)$ of the current as a function of voltage (I/V relationship) recorded in $180 \mathrm{mmol} / \mathrm{l} \mathrm{NMDG}$-Cl solution prior to control $(\triangle)$ and following acute application of $2 \mathrm{~mol} / \mathrm{l}$ DMSO in $180 \mathrm{mmol} / \mathrm{l} \mathrm{NMDG-Cl}$ solution. B. Arithmetic means $( \pm \mathrm{SEM}, n=4)$ of the current as a function of voltage (I/V relationship) recorded in $100 \mathrm{mmol} / \mathrm{l} \mathrm{CaCl} 2$ solution prior to control $(\triangle)$ and following acute application of $2 \mathrm{~mol} / \mathrm{l} \mathrm{DMSO}$ in $100 \mathrm{mmol} / \mathrm{l} \mathrm{CaCl} 2$ solution. C. Arithmetic means $( \pm \mathrm{SEM}, n=3)$ of the current as a function of voltage (I/V relationship) recorded in $150 \mathrm{mmol} / \mathrm{KCl}$ solution prior to control $(\triangle)$ and following acute application of $2 \mathrm{~mol} / \mathrm{l} \mathrm{DMSO}$ in $180 \mathrm{mmol} / 1 \mathrm{KCl}$ solution. D. Percent of cation conductance inhibition ( \pm SEM, $n=3 \div 13$ ) calculated by linear regression for the difference in inward currents at the beginning of experiment and after acute application of $2 \mathrm{~mol} / \mathrm{l}$ DMSO dissolved in the $\mathrm{NaCl}$ Ringer, $180 \mathrm{mmol} / \mathrm{l} \mathrm{NMDG}-\mathrm{Cl}, 100 \mathrm{mmol} / \mathrm{l}$ $\mathrm{CaCl}_{2}, 150 \mathrm{mmol} / \mathrm{l} \mathrm{KCl}, 150 \mathrm{mmol} / \mathrm{l} \mathrm{NaCl}$ and $150 \mathrm{mmol} / \mathrm{l} \mathrm{Na}$-gluconate bath solutions.

had no inhibitory effect on cation conductance in human erythrocytes.

To check whether the blocking effect of DMSO on cation channels activity may be due to its oxidative properties, the whole-cell patch-clamp experiments were performed with a strong oxidant $\left(1 \mathrm{mmol} / \mathrm{L}_{2} \mathrm{O}_{2}\right)$. When applied acutely, $1 \mathrm{mmol} / 1 \mathrm{H}_{2} \mathrm{O}_{2}$ decreased cation conductance of human erythrocytes following the first 2-5 minutes. Further incubation with the oxidant resulted in a significant increase in cation conductance of human erythrocytes (Fig. 5A,B).

We further examined the effect of high DMSO on $\left[\mathrm{Ca}^{2+}\right]_{\mathrm{i}}$. The experiments performed with fluorescent $\mathrm{Ca}^{2+}$ dye Fluo3 showed significantly reduced $\left[\mathrm{Ca}^{2+}\right]_{\mathrm{i}}$ in DMSO treated cells in comparison with control cells (Fig. 6). The effect, however, could relate to quenching of Fluo-3 fluorescence by high DMSO concentration.

\section{Discussion}

The present patch-clamp study on human erythrocytes revealed a gradual concentration-dependent decline in cation conductance induced by DMSO. Inhibitory effect of high concentrations of DMSO was observed for all tested monovalent $\left(\mathrm{Na}^{+}, \mathrm{K}^{+}\right.$and $\left.\mathrm{NMDG}^{+}\right)$as well as for divalent $\left(\mathrm{Ca}^{2+}\right)$ cations suggesting that DMSO affects the non-selective cation channel activity. The observed effect was not due to a decline in lipid cation conductance since $\mathrm{Na}^{+}$conductance measured in our patch-clamp experiments was $10^{4}$ times 


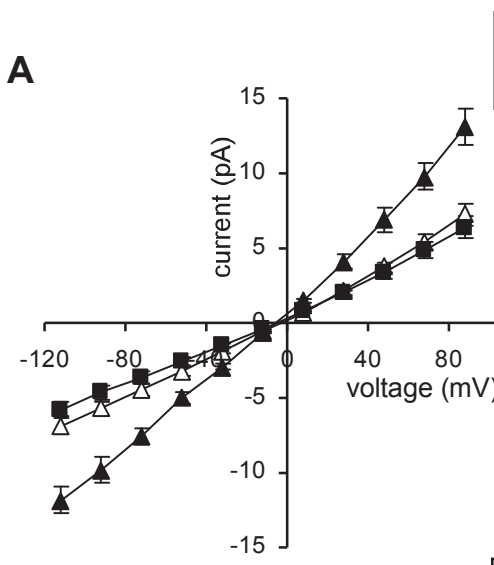

$\triangle$ Ringer

- $1 \mathrm{mmol} / \mathrm{l} \mathrm{H}_{2} \mathrm{O}_{2}$ (2-5 min.)

$\Delta 1 \mathrm{mmol} / \mathrm{L} \mathrm{H} \mathrm{H}_{2} \mathrm{O}_{2}(15-20 \mathrm{~min}$. $)$

A

B

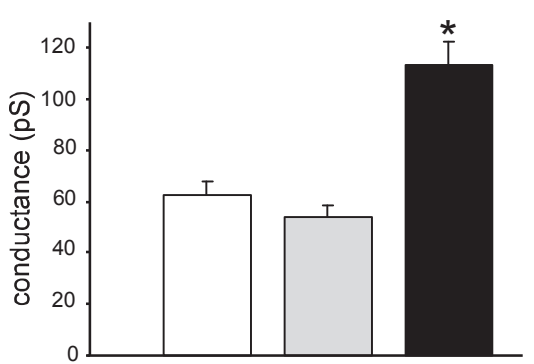

Figure 5. Time-dependent effect of $1 \mathrm{mmol} / \mathrm{l} \mathrm{H}_{2} \mathrm{O}_{2}$ on cation conductance in human erythrocytes. A. Arithmetic means ( \pm SEM, $n=4)$ of the current as a function of voltage (I/V relationship) recorded in the $\mathrm{NaCl}$ Ringer bath solution prior to control $(\triangle)$, following 2-5 min and after 15-20 min of acute application of $1 \mathrm{mmol} / \mathrm{H} \mathrm{H}_{2} \mathrm{O}_{2}$ in $\mathrm{NaCl}$ Ringer bath solution. B. Arithmetic means ( \pm SEM, $n=4$ ) of the conductance (as calculated for the inward currents by linear regression) prior to control $(\square)$, following $2-5$ min and after 15-20 min of acute application of $1 \mathrm{mmol} / 1 \mathrm{H}_{2} \mathrm{O}_{2}$ in $\mathrm{NaCl}$ Ringer bath solution. ${ }^{*}$ significant difference from control $(p \leq 0.05$; paired $t$-test).

higher than that reported for $\mathrm{Na}^{+}$conductance $(0.1 \mathrm{~mol} / \mathrm{l}$ $\mathrm{NaCl}, \mathrm{pH}$ 7.4) of pure lipid bilayers (Cala et al. 1982).

The highest inhibition by $2 \mathrm{~mol} / \mathrm{l} \mathrm{DMSO}$ was observed for the largest monovalent $\left(\mathrm{NMDG}^{+}\right)$among all tested monovalent cations which ruled out lipid bilayer involvement in the DMSO effect.

The cation channels were originally active in our experiments. The calculated value of cation conductance for human erythrocytes in $\mathrm{NaCl}$ Ringer bath solution $(68 \pm 2 \mathrm{pS})$ was in a good agreement with the data of Desai (Desai et al. 2000), who reported less than $100 \mathrm{pS}$ whole-cell conductance for untreated erythrocytes. Interestingly, the value for leak cation current in erythrocyte measured by radiotracers is much lower (Richter et al. 1997) than that measured by whole-cell patch-clamp. The discrepancy could be due to
A

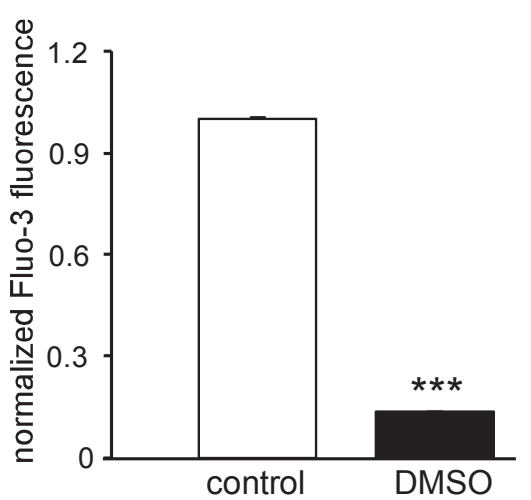

B

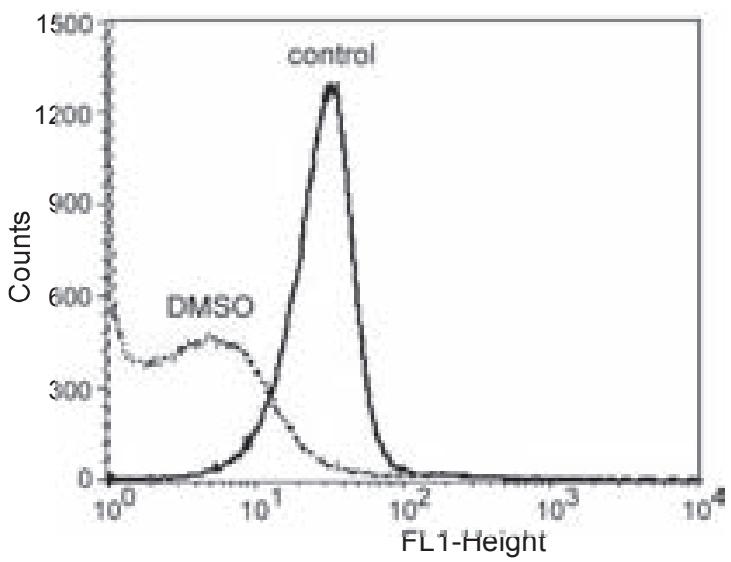

Figure 6. Effect of short-term DMS treatment cytosolic free $\mathrm{Ca}^{2+}$ concentration in human erythrocytes measured by Fluo-3. A. Arithmetic means \pm SEM of normalized Fluo-3 fluorescence of control cells in Ringer solution in the absence $(n=3)$ and after short-term incubation with $2 \mathrm{~mol} / \mathrm{l} \mathrm{DMSO}(n=3)$. ${ }^{* *}$ significant difference from control ( $p \leq 0.001 ; t$-test). B. Histogram of Fluo-3 fluorescence in a representative experiment of human erythrocytes in isotonic Ringer (solid line), and hypertonic Ringer bath solution containing $2 \mathrm{~mol} / \mathrm{l}$ DMSO added (dotted line).

perturbation induced by whole-cell formation in the cell membrane that results in activation of mechanosensitive non-selective cation channels. Mechanosensitive cation channels were found in erythrocyte progenitor cells (K562 cells; Staruschenko and Vedernikova 2002) as well as in mature erythrocyte (Cordero and Romero 2002). Another possible explanation for the difference in cation currents is the use of loop diuretics (furosemide, bumetamide) for $\mathrm{Na}^{+}, \mathrm{K}^{+}, \mathrm{Cl}^{-}$-cotransporter inhibition in radiotracer measurements. The most recent data (Kucherenko et al., 2012) have shown a blocking effect of furosemide on non-selective cation channel activity in human erythrocytes. Noteworthy, a chemical blocker HOE642 inhibited (up to $40 \%$ ) cation leak current in human erythrocytes in isotonic $\mathrm{NaCl}$ bath solution in radiotracer experiments (Bernhardt et al. 2007). 
It suggests that cation channels could be not only activated by toxins or chemical treatment (Tosteson et al. 1991; Qadri et al. 2011) but they have basal activity in untreated human erythrocytes.

DMSO at clinical doses was shown to be a $\mathrm{Na}^{+}$channel blocker and to suppress, in a reversible manner, opening of ionotropic receptor $\mathrm{N}$-methyl-D-aspartate (NMDA) and a-amino-3-hydroxy-5-methyl-4-isoxazolepropionic acid (AMPA) receptor channels, which are known to be activated by glutamate during oxidative or metabolic stress (Karaca et al. 1991; Lu et al. 2001).

Electrophysiological studies revealed several channels expressed in human erythrocytes: the $\mathrm{Ca}^{2+}$-activated $\mathrm{K}^{+}$ channels with the molecular identity of SK4 (KCNN4) (Hoffman et al. 2003), voltage-gated (Bennekou et al. 1993, 2004; Kaestner et al. 1999), and voltage-independent (Huber et al. 2001) non-selective cation channels. The voltageindependent cation channels were shown to be partially related to TRPC3/6/7 channels (Foller et al. 2008). Recent data demonstrated the existence of NMDA receptors in rat (Makhro et al. 2010) and AMPA receptors in human (Föller et al. 2009) erythrocytes. In our recent study (Kucherenko and Lang 2010) we have shown that an AMPA receptor antagonist NASRM (1-naphthyl acetyl spermine) was effective not only in blocking cation currents induced by $\mathrm{Cl}^{-}$removal but also significantly blunted the basal cation conductance in $\mathrm{Cl}^{-}$-containing bath solution. Non-selective blockage by high concentrations of DMSO and its ability to inhibit cation conductance in $\mathrm{Cl}^{-}$containing bath media observed in the present study suggest a possible involvement of AMPA receptor non-selective cation channels. Higher inhibition by DMSO of $\mathrm{Na}^{+}$conductance in isotonic Na-gluconate bath solution in comparison with $\mathrm{NaCl}$ bath solution $(20.8 \pm 1.7 \%$ versus $15.4 \pm 1.6 \%$ ) points out that $\mathrm{DMSO}$ blocks $\mathrm{Cl}^{-}$removal stimulated as well as basal $\mathrm{Na}^{+}$conductance and thus might affect the activity of different types of cation channels in human erythrocytes.

Our present data showing the blocking effect of DMSO on cation conductance seemed to be in conflict with the data of (Santos et al. 2002) which demonstrated that $\mathrm{K}^{+}$, $\mathrm{Na}^{+}$and $\mathrm{Ca}^{2+}$ plasma concentrations are elevated in DMSO-treated cells. The contradiction can be due to the fact that DMSO suppresses $\mathrm{Na}^{+}-\mathrm{K}^{+}$-ATPase as well as $\mathrm{Ca}^{2+}-\mathrm{Mg}^{2+}$-ATPase activities (Rybczyńska and Chmiel 1982; McConnell et al. 1999). Our fluorescent calcium measurements showed significantly lowered intracellular calcium levels in erythrocytes treated with high concentration of DMSO in comparison with native cells. High concentrations of DMSO that permeates into the cells, however, might quench Fluo-3 fluorescence resulting in apparent decline of measured intracellular free calcium levels. Conversely, our direct patch-clamp experiments clearly showed that DMSO affects the activity of non-se- lective cation channels in human erythrocytes suppressing $\mathrm{Ca}^{2+}$ and $\mathrm{Na}^{+}$influxes.

The precise mechanism of DMSO effect on the activity of the non-selective cation channels is unknown since DMSO was shown to have diverse effects on different cell structures. Previous studies have shown that DMSO is a powerful inhibitor of platelet aggregation (Repine et al. 1981; Dujovny et al. 1983), a reaction that might involve the inhibition of prostaglandin platelet-aggregating arachidonic acid metabolites by DMSO (Panganamala et al. 1976). Erythrocytes also participate in a clot formation. Prostaglangin $\mathrm{PGE}_{2}$ which is produced by human erythrocytes was shown to play a key role in the non-selective cation channels activation increasing intracellular free calcium (Lang et al. 2005).

Interestingly, while showing a scavenging effect on free radicals formation, DMSO at the same time demonstrates oxidative properties, being a mild oxidant. A number of cation channels (TRPC3/6 as well) were shown to be activated upon oxidative stress (Poteser et al. 2006; Hecquet and Malik 2009; Graham et al. 2010; Miller and Zhang 2011). Our whole-cell patch-clamp experiments with a strong oxidant $1 \mathrm{mmol} / 1 \mathrm{H}_{2} \mathrm{O}_{2}$ also demonstrated enhanced cation conductance in human erythrocytes. The effect was time-dependent and at the beginning (2-5 min) of oxidation a decline in cation conductance was observed followed by a gradual increase. In the absence of $\mathrm{H}_{2} \mathrm{O}_{2}$, the cells treated with DMSO showed just a declined cation conductance. It is known that oxidative effect of DMSO is mostly due to methionine oxidation to methionine sulfoxide. Moreover, SH groups of proteins are also oxidized but this reaction proceeds after a lag period of 2 hours (Shecher 1986). Participation of SH-groups in the cation channels regulation in human erythrocytes was shown by Duranton (Duranton et al. 2002). Since acute application of a strong oxidant $\left(\mathrm{H}_{2} \mathrm{O}_{2}\right)$ also resulted in a short-term inhibition of the cation conductance in our experiments, it is possible to speculate that the effect was due to methionine oxidation. Thus methionine residues of cation channel-forming membrane proteins might participate in regulation of cation permeability and their oxidation results in suppression of the basal activity of the channels.

Another mechanism by which DMSO might affect the activity of the cation channels in human erythrocyte is connected with the structural properties of the DMSO molecule. DMSO is a strongly polar substance with high dipole moment (3.96 D). Perturbations caused by dipoledipole interactions of DMSO with amino acid residues of proteins forming the channel might influence conductivity of the channels. For example, by way of a concrete calculation, a simple model system like gramicidin channel shows a strong dependence of the conductance obtained on the location and orientation of dipole rings at the channel (Sancho and Martinez 1991). 
In conclusion, we have shown that cytotoxicity of high concentrations of DMSO on human erythrocyte does not relate to the activation of cation channels permeable to $\mathrm{Na}^{+}$and $\mathrm{Ca}^{2+}$. High concentrations of DMSO exert inhibitory effect on the non-selective cation channels activity in human erythrocytes. Reduced activity of the cation channels upon the treatment with high concentration of DMSO protects the cells against excessive $\mathrm{Na}^{+}$and $\mathrm{Ca}^{2+}$ download; preventing accelerated cell death and lowing cell aggregation.

Acknowledgement. We thank Prof. Florian Lang (Physiology Institute I, Eberhard-Karls University of Tübingen, Germany) for a fellowship to YVK. We additionally thank Prof. Uwe R. Fischer (Department of Physics and Astronomy, Seoul National University, Korea) for the critical reading and Mr. David A. Erickson (Phoenix, USA) for correction of the manuscript.

\section{References}

Adler S. G., Lachant N. A., Anderson P. S., Cohen A. H., Davidson W. D., Glassock R. J. (1991): Dimethyl sulfoxide enhances hexose monophosphate shunt activity in cultured glomerular mesangial cells, leukocytes and erythrocytes. Miner. Electrolyte Metab. 17, 52-57

Asmis L., Tanner F. C., Sudano I., Lüscher T. F., Camici G. G. (2010): DMSO inhibits human platelet activation through cyclooxygenase-1 inhibition. A novel agent for drug eluting stents? Biochem. Biophys. Res. Commol/lun. 391, $1629-1633$

Barry P. H., Lynch J. W. (1991): Liquid junction potentials and small cell effects in patch-clamp analysis. J. Membr. Biol. 121, 101-117 http://dx.doi.org/10.1007/BF01870526

Benaim G., de Meis L. (1990): Similarities between the effects of dimethyl sulfoxide and calmodulin on the red blood cell Ca2(+)-ATPase. Biochim. Biophys. Acta 1026, 87-92 http://dx.doi.org/10.1016/0005-2736(90)90336-M

Bennekou P. (1993): The voltage-gated non-selective cation channel from human red cells is sensitive to acetylcholine. Biochim. Biophys. Acta 1147, 165-167 http://dx.doi.org/10.1016/0005-2736(93)90328-W

Bennekou P., Barksmann T. L., Jensen L. R., Kristensen B. I., Christophersen P. (2004): Voltage activation and hysteresis of the non-selective voltage-dependent channel in the intact human red cell. Bioelectrochemistry 62, 181-185 http://dx.doi.org/10.1016/j.bioelechem.2003.08.006

Bernhardt I., Weiss E., Robinson H. C., Wilkins R., Bennekou P. (2007): Differential effect of HOE642 on two separate monovalent cation transporters in the human red cell membrane. Cell Physiol. Biochem. 20, 601-606 http://dx.doi.org/10.1159/000107543

Boiko N. M., Bondarenko V. A., Belous A. M. (1982): Factors of avian erythrocyte fusion: changes in the state of plasma membrane induced by dimethylsulfoxide and temperature Biokhimiia 47, 896-903 (in Russian)
Brien S., Prescott P., Bashir N., Lewith H., Lewith G. (2008): Systematic review of the nutritional supplements dimethyl sulfoxide (DMSO) and methylsulfonylmethane (MSM) in the treatment of osteoarthritis. Osteoarthritis Cartilage 16, $1277-1288$ http://dx.doi.org/10.1016/j.joca.2008.03.002

Brockbank K. G., Wright G. J., Yao H., Greene E. D., Chen Z. Z., Schenke-Layland K. (2011): Allogeneic heart valve storage above the glass transition at $-80^{\circ} \mathrm{C}$. Ann. Thorac. Surg. 91, 1829-1835 http://dx.doi.org/10.1016/j.athoracsur.2011.02.043

Cala P. M., Norby J. G., Tosteson D. C. (1982): Effects of the plant alkaloid sanguinarine on cation transport by human red blood cells and lipid bilayer membranes. J. Membr. Biol. 64, 23-31 http://dx.doi.org/10.1007/BF01870765

Camici G. G., Steffel J., Akhmedov A., Schafer N., Baldinger J., Schulz U., Shojaati K., Matter C. M., Yang Z., Lüscher T. F., Tanner F. C. (2006): Dimethyl sulfoxide inhibits tissue factor expression, thrombus formation, and vascular smooth muscle cell activation: a potential treatment strategy for drug-eluting stents. Circulation 114, 1512-1521 http://dx.doi.org/10.1161/CIRCULATIONAHA.106.638460

Cordero J. F., Romero P. J. (2002) Caffeine activates a mechanosensitive $\mathrm{Ca}\left({ }^{2+}\right)$ channel in human red cells. Cell Calcium 31, $189-200$ http://dx.doi.org/10.1016/S0143-4160(02)00032-5

Desai S. A., Bezrukov S. M., Zimmerberg J. (2000): A voltage-dependent channel involved in nutrient uptake by red blood cells infected with the malaria parasite. Nature 406, 1001-100 http://dx.doi.org/10.1038/35023000

Dkhar P., Sharma R. (2010): Effect of dimethylsulphoxide and curcumin on protein carbonyls and reactive oxygen species of cerebral hemispheres of mice as a function of age. Int. J. Dev. Neurosci. 28, 351-357 http://dx.doi.org/10.1016/j.ijdevneu.2010.04.005

Dujovny M., Rozario R., Kossovsky N., Diaz F. G., Segal R. (1983): Antiplatelet effect of dimethyl sulfoxide, barbiturates, and methyl prednisolone. Ann. NY Acad. Sci. 411, 234-244 http://dx.doi.org/10.1111/j.1749-6632.1983.tb47304.x

Duranton C., Huber S. M., Lang F. (2002): Oxidation induces a $\mathrm{Cl}(-)$-dependent cation conductance in human red blood cells. J. Physiol. 539, 847-855 http://dx.doi.org/10.1113/jphysiol.2001.013040

Fahim F. A., Esmat A.Y, Mady E. A., Ibrahim E. K. (2003): Antitumor activities of iodoacetate and dimethylsulphoxide against solid Ehrlich carcinoma growth in mice. Biol. Res. 36, 253-262 http://dx.doi.org/10.4067/S0716-97602003000200015

Foller M., Kasinathan R. S., Koka S., Lang C., Shumilina E., Birnbaumer L., Lang F., Huber S. M. (2008): TRPC6 contributes to the $\mathrm{Ca}\left({ }^{2+}\right)$ leak of human erythrocytes. Cell. Physiol. Biochem. 21, 183-192 http://dx.doi.org/10.1159/000113760

Föller M., Mahmud H., Gu S., Kucherenko Y., Gehring E. M., Shumilina E., Floride E., Sprengel R., Lang F. (2009): Modulation of suicidal erythrocyte cation channels by an AMPA antagonist. J. Cell. Mol. Med. 13, 3680-3686 http://dx.doi.org/10.1111/j.1582-4934.2009.00745.x 
Goddu S. M., Narra V. R., Harapanhalli R. S., Howell R. W., Rao D. V. (1996): Radioprotection by DMSO against the biological effects of incorporated radionuclides in vivo--Comparison with other radioprotectors and evidence for indirect action of Auger electrons Acta Oncol. 35, 901-907 http://dx.doi.org/10.3109/02841869609104044

Goodnough J., Allen N., Nesham M. E., Clendenon N. R. (1980): The effect of dimethyl sulfoxide on gray matter injury in experimental spinal cord trauma. Surg. Neurol. 13, 273-276

Graham S., Ding M., Ding Y., Sours-Brothers S., Luchowski R., Gryczynski Z., Yorio T., Ma H., Ma R. (2010): Canonical transient receptor potential 6 (TRPC6), a redox-regulated cation channel. J. Biol. Chem. 285, 23466-23476 http://dx.doi.org/10.1074/jbc.M109.093500

Haack-Sørensen M., Kastrup J. (2011): Cryopreservation and revival of mesenchymal stromal cells. Methods Mol. Biol. 698, 161-174 http://dx.doi.org/10.1007/978-1-60761-999-4_13

Hanslick J. L., Lau K., Noguchi K. K., Olney J. W., Zorumski C. F., Mennerick S., Farber N. B. (2009): Dimethyl sulfoxide (DMSO) produces widespread apoptosis in the developing central nervous system. Neurobiol. Dis. 34, 1-10 http://dx.doi.org/10.1016/j.nbd.2008.11.006

Hecquet C. M., Malik A. B. (2009): Role of $\mathrm{H}(2) \mathrm{O}(2)$-activated TRPM2 calcium channel in oxidant-induced endothelial injury. Thromb. Haemost. 101, 619-625

Hoffman J. F., Joiner W., Nehrke K., Potapova O., Foye K., Wickrema A. (2003): The hSK4 (KCNN4) isoform is the $\mathrm{Ca}^{2+}$-activated $\mathrm{K}+$ channel (Gardos channel) in human red blood cells. Proc. Natl. Acad. Sci. U.S.A. 100, 7366-7371 http://dx.doi.org/10.1073/pnas.1232342100

Homer N. Z., Reglinski J., Sowden R., Spickett C. M., Wilson R., Walker J. J. (2005): Dimethylsulfoxide oxidizes glutathione in vitro and in human erythrocytes: kinetic analysis by $1 \mathrm{H}$ NMR. Cryobiology 50, 317-324 http://dx.doi.org/10.1016/j.cryobiol.2005.04.002

Huber S. M., Gamper N., Lang F. (2001): Chloride conductance and volume-regulatory nonselective cation conductance in human red blood cell ghosts. Pflügers Arch. 441, 551-558 http://dx.doi.org/10.1007/s004240000456

Iida C., Fujii K., Koga E., Washino Y., Ichi I., Kojo S. (2007): Inhibitory effect of dimethyl sulfoxide (DMSO) on necrosis and oxidative stress caused by D-galactosamine in the rat liver. J. Nutr. Sci. Vitaminol. (Tokyo) 53, 160-165 http://dx.doi.org/10.3177/jnsv.53.160

Jacob S. W., de la Torre J. C. (2009): Pharmacology of dimethyl sulfoxide in cardic ans CNS damage. Pharmacol. Rep. 61, 225-235

Jagota S. K. (1992): Inhibition of acetylcholinesterase of mice erythrocytes \& synaptosomes by dimethylsulfoxide. Indian J. Med. Res. 96, 275-278

Kaestner L., Bollensdorff C., Bernhardt I. (1999): Non-selective voltage-activated cation channel in the human red blood cell membrane. Biochim. Biophys. Acta 1417, 9-15 http://dx.doi.org/10.1016/S0005-2736(98)00240-5

Karaca M., Bilgin U. Y., Akar M., de la Torre J. C. (1991): Dimethly sulphoxide lowers ICP after closed head trauma. Eur. J. Clin. Pharmacol. 40, 113-114 http://dx.doi.org/10.1007/BF00315149
Kim R., Liu W., Chen X., Kreder K. J., Luo Y. (2011): Intravesical dimethyl sulfoxide inhibits acute and chronic bladder inflammation in transgenic experimental autoimmune cystitis models. J. Biomed. Biotechnol. 2011, 937061 http://dx.doi.org/10.1155/2011/937061

Kucherenko Y. V., Lang F. (2010): Inhibition of cation channels in human erythrocytes by spermine. J. Membr. Biol. 237, 93-106 http://dx.doi.org/10.1007/s00232-010-9310-1

Kucherenko Y. V., Lang F. (2012): Inhibitory effect on non-selective voltage-independent cation channels in human erythrocytes. Cell. Physiol. Biochem. 30, 863-875 http://dx.doi.org/10.1159/000341464

Lang P. A., Kempe D. S., Myssina S., Tanneur V., Birka C., Laufer S., Lang F., Wieder T., Huber S. M. (2005): PGE(2) in the regulation of programmed erythrocyte death. Cell Death Differ. 12, 415-428 http://dx.doi.org/10.1038/sj.cdd.4401561

Lehotský J., Raeymaekers L., Casteels R. (1992): Effects of dimethyl sulfoxide and polycationic neomycin on stimulation of purified plasma membrane $\mathrm{Ca}\left({ }^{2+}\right)$-pump by negatively charged phospholipids. Gen. Physiol. Biophys. 11, 567-577

Lu C., Mattson M. P. (2001): Dimethyl sulfoxide suppresses NMDA- and AMPA-induced ion currents and calcium influx and protects against excitotoxic death in hippocampal neurons. Exp. Neurol. 170, 180-185 http://dx.doi.org/10.1006/exnr.2001.7686

Makhro A., Wang J., Vogel J., Boldyrev A. A., Gassmann M., Kaestner L., Bogdanova A. (2010): Functional NMDA receptors in rat erythrocytes. Am. J. Physiol. Cell. Physiol. 298, C1315-1325 http://dx.doi.org/10.1152/ajpcell.00407.2009

McConnell E. J., Wagoner M. J., Keenan C. E., Raess B. U. (1999): Inhibition of calmodulin-stimulated $\left(\mathrm{Ca}^{2+}+\mathrm{Mg}^{2+}\right)$-ATPase activity by dimethyl sulfoxide. Biochem. Pharmacol. 57, 39-44 http://dx.doi.org/10.1016/S0006-2952(98)00259-7

McGee B. A., Barnett M. D., Small R. E. (1991): Current options for the treatment of systemic scleroderma. Clin. Pharm. 10, $14-25$

Miller B. A., Zhang W. (2011): TRP channels as mediators of oxidative stress. Adv. Exp. Med. Biol. 704, 531-544 http://dx.doi.org/10.1007/978-94-007-0265-3_29

Mobarok Ali A. T. (1998): The role of non-protein sulphydryls in the protective effects of antioxidants against ethanol-induced vascular permeability changes in the rat stomach. Inflammopharmacology 6, 41-51 http://dx.doi.org/10.1007/s10787-998-0005-5

Motta J. P., Gomes B. E., Bouzas L. F., Paraguassú-Braga F. H., Porto L. C. (2010): Evaluations of bioantioxidants in cryopreservation of umbilical cord blood using natural cryoprotectants and low concentrations of dimethylsulfoxide. Cryobiology 60, 301-307

http://dx.doi.org/10.1016/j.cryobiol.2010.02.002

Panganamala R. V., Sharma H. M., Heikkila R. E., Geer J. C., Cornwell D. G. (1976): Role of hydroxyl radical scavengers dimethyl sulfoxide, alcohols and methional in the inhibition of prostaglandin biosynthesis. Prostaglandins 11, 599-607 http://dx.doi.org/10.1016/0090-6980(76)90063-0 
Parisi A., Alfieri A., Mazzella M., Mazzella A., Scognamiglio M., Scognamiglio G., Mascolo N., Cicala C. (2010): Protective effect of dimethyl sulfoxide on acute myocardial infarction in rats. J. Cardiovasc. Pharmacol. 55, 106-109 http://dx.doi.org/10.1097/FJC.0b013e3181c87a65

Poteser M., Graziani A., Rosker C., Eder P., Derler I., Kahr H., Zhu M. X., Romanin C., Groschner K. (2006): TRPC3 and TRPC4 associate to form a redox-sensitive cation channel. Evidence for expression of native TRPC3-TRPC4 heteromeric channels in endothelial cells. J. Biol. Chem. 281, 13588-13595 http://dx.doi.org/10.1074/jbc.M512205200

Qadri S. M., Kucherenko Y., Zelenak C., Jilani K., Lang E., Lang F. (2011): Dicoumarol activates $\mathrm{Ca}^{2+}$-permeable cation channels triggering erythrocyte cell membrane scrambling. Cell Physiol. Biochem. 28, 857-864 http://dx.doi.org/10.1159/000335800

Repine J. E., Pfenninger O. W., Talmage D. W., Berger E. M., Pettijohn D. E. (1981): Dimethyl sulfoxide prevents DNA nicking mediated by ionizing radiation or iron/hydrogen peroxide-generated hydroxyl radical. Proc. Natl. Acad. Sci. U.S.A. 78, 1001-1003 http://dx.doi.org/10.1073/pnas.78.2.1001

Richter S., Hamann J., Kummerow D., Bernhardt I. (1997): The monovalent cation „leak“ transport in human erythrocytes: an electroneutral exchange process. Biophys. J. 73, 733-745 http://dx.doi.org/10.1016/S0006-3495(97)78106-2

Romero P. J. (1992): Inhibition of the human erythrocyte calcium pump by dimethyl sulfoxide. Cell Calcium 13, 659-667 http://dx.doi.org/10.1016/0143-4160(92)90076-5

Rybczyńska M., Chmiel J. (1982): Effect of various sulfur compounds on the transport system enzymes in human erythrocyte membranes. Pol. J. Pharmacol. Pharm. 34, 177-182
Sancho M., Martinez G. (1991): Electrostatic modeling of dipole-ion interactions in gramicidinlike channels. Biophys. J. 60, 81-88 http://dx.doi.org/10.1016/S0006-3495(91)82032-X

Santos N. C., Figueira-Coelho J., Saldanha C., Martins-Silva J. (2002): Biochemical, biophysical and haemorheological effects of dimethylsulphoxide on human erythrocyte calcium loading. Cell Calcium 31, 183-188

http://dx.doi.org/10.1054/ceca.2002.0271

Shechter Y. (1986): Selective oxidation and reduction of methionine residues in peptides and proteins by oxygen exchange between sulfoxide and sulfide. J. Biol. Chem. 261, 66-70

Small W. C., Goldstein J. H. (1982): The effect of the cryoprotectants, dimethylsulfoxide and glycerol on water transport in the human red blood cell. Biochim. Biophys. Acta 720, 81-86 http://dx.doi.org/10.1016/0167-4889(82)90041-6

Staruschenko A. V., Vedernikova E. A. (2002): Mechanosensitive cation channels in human leukaemia cells: calcium permeation and blocking effect. J. Physiol. 541, 81-90 http://dx.doi.org/10.1113/jphysiol.2001.015222

Tiffert J. T., Bookchin R. M., Lew V. L. (2003): Calcium homeostasis in normal and abnormal human red cells. In: Red Cell Membrane Transport in Health and Disease. (Eds. I. Bernhardt and J. C. Ellory), pp. 373-405, Berlin and Heidelberg, Springer Verlag, Germany

Tosteson M. T., Halperin J. A., Kishi Y., Tosteson D. C. (1991): Palytoxin induces an increase in te cation conductance of red cells. J. Gen. Physiol. 98, 969-985 http://dx.doi.org/10.1085/jgp.98.5.969

Recived: October 17, 2011

Final version accepted: September 6, 2012 